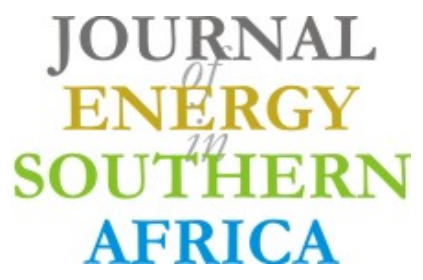

\title{
Long-term temperature measurement: Biogas digesters fermenting slurry
}

\author{
Vhutshilo Nekhubvi*, David Tinarwo ${ }^{2}$ \\ ${ }^{1}$ Department of Science Foundation, University of Venda, Private bag X5050, Thohoyandou 0950, South Africa \\ ${ }^{2}$ Department of Physics, University of Venda, Private bag X5050, Thohoyandou 0950, South Africa
}

\section{Abstract}

This paper reports the results of the temperature profile of the unheated and unstirred continuous fermenting bio-slurry in a fixed-dome Deenbandhu 2000 model. The digester is a brick-built system of bulk size $6 \mathrm{~m}^{3}$. The digester was monitored for eight months, measuring internal bio-slurry temperature. A K-type nickel chromium-nickel temperature sensor with a sensitivity of approximately $41 \mu \mathrm{V}^{\circ} \mathrm{C}$ and response time of $0.8 \mathrm{~s}$ in liquids was positioned at the centre of the digester to measure the slurry temperature. The sensor was connected to the data logger and programmed to record temperature readings every second for the entire study period. The study results reported give a clear indication about the reaction of bio-slurry temperature in the digester at a local level, particularly for the eight months' period, which covered all seasons. The calculated values of the daily average temperature reveal that the digester was operating within the range of psychrophilic $10.32^{\circ} \mathrm{C}$ and mesophilic $28.80^{\circ} \mathrm{C}$, although it sometimes operated at $35^{\circ} \mathrm{C}$ and above during certain hours in summer. This study is useful for anaerobic digestion processes for biogas production. The results obtained can be used as a basis to estimate the amount of heat required to raise the temperature
\end{abstract}

of digesters to reach an optimum temperature of mesophilic digesters.

Keywords: renewable energy, thermocouple, mesophilic, bacteria, biomass

\section{Highlights}

- The measurements rely on the K-type nickel chromium-nickel temperature sensors.

- The temperature is measured at the centre of the digester.

- The digester considered is a fixed-dome, brickbuilt Deenbandhu 2000 model.

- The digester is unheated, unstirred and buried underground.

- The soil pH at $0.0 \mathrm{~cm}$ is 5.0 in potassium chlorine.
Journal of Energy in Southern Africa 28(3):99-106

DOI: http://dx.doi.org/10.17159/2413-3051/2017/v28i3a1437

Published by the Energy Research Centre, University of Cape Town ISSN: 2413-3051

http://journals.assaf.org.za/jesa

Sponsored by the Department of Science and Technology 


\section{Introduction}

Most countries are implementing renewable energy sources such as bio-energy as an alternative future energy resource. This is due to the increasing concern about the man-made activities that are known to be emitting greenhouse gases harmful to the environment and human health. Biogas is one of these bio-energy sources. Biogas is defined as a composition of gases generated from anaerobic digestion of organic degradable material. In general terms, anaerobic digestion technology for capturing biogas is used to minimise the risk of water contamination caused by wastewater treatment plants and agricultural activities. In this study, anaerobic digestion is regarded as one of the most efficient technologies for supplying clean energy, particularly digesters which operate using biomass with high water content. The fermentation process of organic materials and their conversion through biological and chemical stages for anaerobic digestion technology have been well studied (Appels et al., 2008). When conditions are best, organic material in a digester can produce biogas containing up to $88 \%$ volume of methane $\left(\mathrm{CH}_{4}\right)$ (Huang and Crookes, 1998). Biogas is considered to be one of the most environmentally friendly and sustainable fuels (Bhat et al., 2001). Limmeechokchai and Chawana (2007) indicated that biogas has the potential to replace utilisation of non-environmentally friendly fuels, while replacing firewood with biogas makes cooking easier, cleaner and safer (Mwirigi et al., 2009). Planning and implementing a successful anaerobic digestion project is driven by the setup of the selected area and also by the approach of the project initiator to the government and community leaders. In many African countries, various types of digesters have been implemented, mostly by non-government organisations, although only a few are operational (Parawira, 2009). Xiaohua et al (2007) indicated that the construction of biogas digesters has positive effects on the economy, society, ecology and environment. Many developing countries, such as Colombia, Ethiopia, Tanzania, Vietnam, Cambodia and Bangladesh, promoted low-cost bio-digester technology with the aim of reducing production costs through using local materials and simplifying installation and operation (Mwakaje, 2008). According to Igoni et al. (2008), a variety of digester types exist for the anaerobic treatment of organic wastes. Various types of small-to-medium-scale biogas digesters have been developed, including the floating drum, fixed dome, and plastic bag types (Amigun and Von Blottnitz, 2007). An inexpensive biogas digester design within the reach of the rural poor is the fixed dome type, which features a basic principle of minimising the surface area of the equipment and reducing installation costs without compromising operating efficiency (Walekhwa et al., 2009). In Limpopo, the preferred digester type is brick-built and fixeddome. It is considered cheap and easy to build, with low maintenance compared with the prefabricated fixed-dome plastic digester and tube digester. Most of the installed digesters are $6 \mathrm{~m}^{3}$, with an expected daily gas production of $1 \mathrm{~m}^{3}$. Almost all these smallscale household digester types are only heated by solar radiation flux striking the soil surface and transmitted through the biogas digester's cover.

According to Amigun and Blottnitz (2010), the development of the first biogas digesters in South Africa dates back to the 1950s. Site visits and personal consultations revealed that there were approximately 450 biogas digesters installed in South Africa in 2015, although the records of most of these digesters were not available to the National Energy Regulator (NERSA). This number is small compared to the estimated twelve million household size biogas digesters in India in 2010 (Martin and Khan, 2016). This suggests that biogas technology has not been effectively adopted in South Africa. Moreover, NERSA (2013) released a media statement stating that there were only 38 small biogas projects registered and operational since 2011 in the KwaZuluNatal, Limpopo, Free State, Western Cape and Gauteng provinces of South Africa. In KwaZulu-Natal only six approved biogas production operations are situated in Izimpongo, Melmoth, and Mgwabi Village at Eshowe. In Limpopo all 21 biogas production operations approved are situated in Giyani Village of the Mopani district municipality. In Gauteng there is only one approved biogas production operation, in Pretoria. No information on the approved number of biogas operations in the Free State and Western Cape is available. All the approved smallscale biogas digesters are not connected to the national gas pipeline grid and are not required to be licensed - although they must be registered with NERSA (NERSA, 2013). These digesters produce biogas from pig manure, cow ding, kitchen waste and agricultural residues.

The small number may be influenced by the fact that South Africa does not have standards for biogas installation as indicated by the South African National Energy Development Institute (SANEDI, 2014). Martin and Khan (2016) highlighted the lack of technical knowledge as a major factor that prevents a widespread adoption of biogas digesters and the type of the feedstock. There are several studies reporting production of biogas utilising different biowaste sources. Karellas (2010) showed that different feedstock is forwarded to an anaerobic digestion system according to feedstock availability, activities in the region of application and economic considerations. An anaerobic digestion system does not operate on a specified input stream, but on a combination of different biomass input streams with variable compositions that constitute the feedstock mixture. 
The study conducted by Parawira (2009) to review biogas technology status, constraints and prospects in Africa reported poor technical quality as a factor that prevents widespread use of small-scale biogas digesters. South Africa has, however, has undertaken measures to promote biogas technology, including the establishment of the Southern African Biogas Industry Association (SABIA). Amongst other the technical factor for the adoption of biogas technology, operating temperature which is a physical factor plays an important role. Singh et al. (1995) indicated that low production of biogas and digester failure is linked to low temperatures. construction of Biogas digesters seems to be gaining momentum in the Limpopo province, especially in Mopani and Vhembe district municipalities. However, research and communication articles such as those by Hlungwani (2009), Kotzé (2014) and Maxwell (2014) have focused on where, how, when a biogas project was implemented, for what purpose and who funded it. Information about the operating temperature for the household digesters in Limpopo province of South Africa is, therefore, lacking.

\subsection{Internal bio-slurry temperature in anaer- obic digestion}

Researchers have widely focused on how temperature influences the production of biogas (Kalia and Kanwar, 1998; Pham et al., 2014; Alkhamis et al., 2000), irrespective of digester designs or installations. Dhaked et al. (2010) stated that there are four temperature ranges for anaerobic digestion process: thermophilic temperature range $\left(45-60^{\circ} \mathrm{C}\right)$, mesophilic temperature range $\left(30-40{ }^{\circ} \mathrm{C}\right)$ psychrotrophic temperature range $\left(20-30{ }^{\circ} \mathrm{C}\right)$, and psychrophilic temperature range $\left(<20{ }^{\circ} \mathrm{C}\right.$. Kalia and Kanwar (1998) evaluated a $3 \mathrm{~m}^{3}$ fixed-dome janta biogas digester in hilly conditions at an altitude of $1300 \mathrm{~m}$ above the mean sea level. Their interest was to measure the bio-slurry temperature at the centre of the digester plant and the ambient temperature using platinum resistance temperature probes coupled with a multi-channel data logger set to record temperature at hourly intervals. Results showed that the digester temperature remains in the lower psychrotrophic range $\left(16-24{ }^{\circ} \mathrm{C}\right)$ for nearly eight months from March to October, and in a psychrophilic temperature range $\left(13-14{ }^{\circ} \mathrm{C}\right)$ for the rest of the year. It is evident that the measured temperature range was always below the optimum temperature $\left(32-35{ }^{\circ} \mathrm{C}\right.$ ) required for gas production (Kalia and Kanwar, 1998). The micro-organisms growth rate of the anaerobic digestion system improves in mesophilic and thermophilic conditions (Shaheen and Nene, 2014). This improvement also plays a major role in the rate of methane production. The governing equation that is used to estimate the methane production rate has been well studied and is given by Equation 1, used in the model of Chen and Hashimoto (1979):

$$
\gamma=\left(\frac{B_{0} S_{0}}{H R T}\right)\left(1-\frac{k}{H R T^{*} \mu_{m}-1+k}\right)
$$

where the values of overall production yield $B_{o}$ is the inflow volatile solids; $S_{o}$ is the concentration of organic components in the cow dung; HRT is the hydraulic retention time; $\mu_{m}$ is the maximum specific growth rate of microorganisms of cow dung as a function of the temperature of the slurry inside the digester; and $k$ represents the kinetic constant. The maximum specific growth and kinetic growth can be estimated using Equations 2 and 3:

$$
\mu_{m}=0.6+0.0039 e^{0.11881^{*} T_{s}}
$$

where $T_{s}$ represents bio-slurry temperature.

$$
k=0.6+0.0206 e^{0.051 * S_{0}}
$$

where $S_{o}$ is the concentration of organic components in the cow dung. The concentration of organic components is well defined in the study by Pham et al. (2014), who applied Equation 1. Utilising the same equation, Kalia and Kanwar (1998) reported the effect of temperature on the production of biogas. They found that lowering the digester temperature from $23-24{ }^{\circ} \mathrm{C}$ in summer months and to $13-14{ }^{\circ} \mathrm{C}$ in winter months resulted in a decrease of gas production by $23-37 \%$. Kalia and Kanwar's (1998) study agrees with that of Alkhamis et al. (2000), which indicates that heating the bio-digester to a temperature of about $35{ }^{\circ} \mathrm{C}$ is important for mesophilic bacteria growth and activity to obtain optimum biogas production. Martin and Khan (2016) conducted a study on the review of biogas digester technology in rural Bangladesh and one of the findings was on the impact of internal temperature on biogas production throughout the digestion process. When the temperature fell below $12{ }^{\circ} \mathrm{C}$ (especially during winter, of course), very low biogas production rates resulted. In the study, the average temperature inside the digester remained at $19-26^{\circ} \mathrm{C}$, which is a psychrotrophic condition. It is evident that the measured digester temperatures did not result in higher gas yields since the optimum temperature range for high gas yield was mesophilic temperature.

Terradas-III et al. (2014) developed a thermic model to predict biogas production in an unheated fixed-dome digester buried underground and predicted temperatures of the slurry inside the digester. 
The temperature of the slurry was then used to predict biogas. The digester was reportedly made from fibreglass. Their validation results were based on the time evolution for the predicted and the measured digester temperatures over seven months with the root square of approximately 1. Aburas et al. (1995) investigated a biogas digester at the University Farm in Jordan with a $16 \mathrm{~m}^{3}$ active volume, made in the shape of a cube below ground level, with curved corners and a flat roof, and constructed out of concrete. The results showed that ambient temperature has an effect on the digester's temperature. Ambient temperature was always greater than the digester's temperature except on the one day when the temperatures were equal. It can be inferred that the ambient temperature is a good predictor of the slurry temperature only for a short period of time. Mukumba et al. (2015) investigated the variation of slurry temperatures of an off-ground batch digester with uncovered dome at different days during the beginning of the summer month of September at the University of Fort Hare, Eastern Cape, South Africa. The results showed the interdependence of slurry, biogas and ambient temperatures over a short period. Weatherford and Zhai (2015) argued that people in colder climates and higher altitude cannot take advantage of anaerobic digestion because of the low temperature of the slurry, although the study used a tubular polyethylene bio-digester.

The aim of the present study was, therefore, to monitor the temperature of the bio-slurry inside the unstirred, unheated biogas digester. The present study gives an indication about the reaction of slurry temperature within the digester at a local level, for eight months covering both winter and summer. Brick-built biogas digesters were constructed underground, so that the energy to heat them could only be associated with solar radiation falling on the system's specific location - meaning that an incoming amount of solar radiation striking the soil surface could affect the internal temperature of the digester installed.

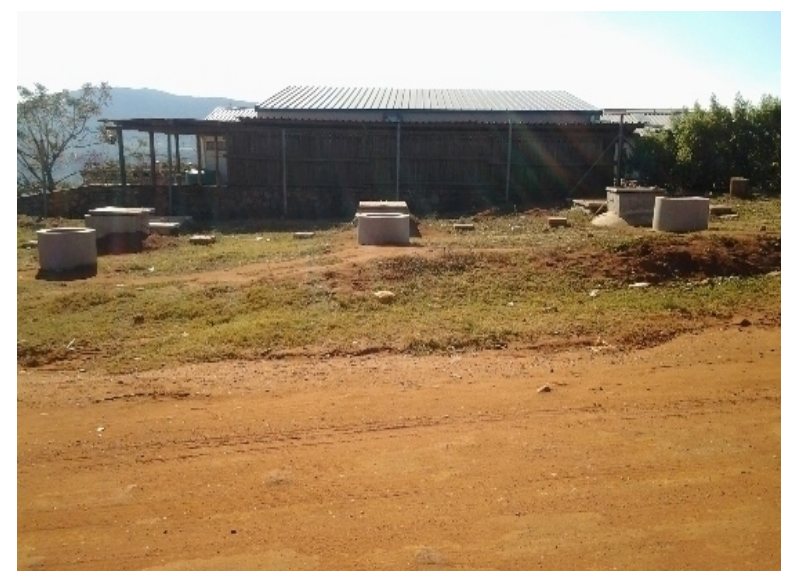

Figure 1: The three brick-built digesters.

\section{Material and methods \\ 2.1 Study location}

A selected site for this study is the rural-based Vele Secondary School in the Thulamela local municipality of Vhembe district, Limpopo province, South Africa (geographical coordinates: $22^{\circ} 45^{\prime} 56.08^{\prime \prime S}$, $\left.30^{\circ} 20^{\prime} 34.44 " \mathrm{E}\right)$. Vhembe's climate is typically subtropical, with mild, moist winters and wet, warm summers. The annual temperature profile ranges from $10^{\circ} \mathrm{C}$ during winter up to $40^{\circ} \mathrm{C}$ during summer (Mutale Municipality, 2012).

\subsection{Experimental}

Three fixed-dome brick-built biogas digesters of bulk size $6 \mathrm{~m}^{3}$, as shown in Figure 1, were monitored for a period of eight months (May to December 2015), measuring internal slurry temperature. The digesters are separated by $2 \mathrm{~m}$. The experimental period covered winter and summer, with days of rainfall, cold and warm conditions which affected the temperature of the digestion process. The digesters were constructed following the design of a fixed-dome Deenbandhu 2000 model in India (Cheng et al., 2013). Its main components include a bowl-shaped foundation with a collar around the circumference, gas outlet pipe fitted on top of the dome surface, a $110.0 \mathrm{~mm}$ x $2.0 \mathrm{~m}$ PVC inlet pipe connected to a small mixing tank and an outlet which is a rectangular tank of volume $1.2 \mathrm{~m} \times 1.0 \mathrm{~m} \times 1.1 \mathrm{~m}$ a part of the digester where the bio-slurry is stored after it has been discharged through the small opening on the bottom part of the dome. The dome also has an upper and bottom part. This part of the digester was covered with a rectangular slab to avoid substantial heat loss. The bottom part of the dome is where the bio-slurry is stored to initiate the fermentation process and the upper part is where the generated gas by the fermenting slurry is stored before utilisation. The upper part is also known as the gas chamber and its volume is equivalent to the volume of the outlet tank. They were all built underground using the following materials:

- cement bricks (20 x $10 \times 6.5 \mathrm{~cm})$ usually used for building houses in the area, each with thermal conductivity of $0.8 \mathrm{~W} /(\mathrm{mK})$ a value that agrees with the thermal cocundctivity of a brick in the study of Mukumba et al. (2015);

- a $20 \mathrm{~cm}$ concrete slab at the bottom of the digester; and

- the inner and outer walls of the digester were plastered, and only painted with waterproofing paint inside the digester to prevent gas and water leakage.

The dome of the selected digester was not covered during the study. The digester was first filled with $2500 \mathrm{~L}$ of clean ground water with a pH of 6.0 7.0. A compressor was used to preasurise the digesters in order to check for leakages. A maximum 
of $10 \mathrm{kpa}$ was pumped into each digester through the gas outlet pipe and the change in presure was monitored for the period of nine hours. When it was confirmed that there was no change in pressure, fresh cow dung was collected from local cattleowners and feedlots around the village. To initiate the process, the digesters were filled with $2500 \mathrm{~L}$ of clean water and then loaded with $180 \mathrm{~kg}$ of cow dung mixed with $180 \mathrm{~L}$ of water. The digester was continuously fed daily with $20 \mathrm{~kg}$ of cow dung mixed with $20 \mathrm{~L}$ of water to allow it to completely close the opening at the outlet side of the digester. This procedure is also used to prevent the gas from escaping through the outlet side. The properties (specific heat capacity, thermal conductivity, and density) of the daily feed were assumed to be equivalent to the properties of the mixture throughout any location inside the digester. A sufficiently flammeable methane gas $\left(\geq 51 \% \mathrm{CH}_{4}\right)$ was detected by a hand-held Riken Niken gas detector of model GLX 2012 on 21 April 2015, or after 42 days, for all the digesters.

\subsection{Measurements of internal slurry temperature and ambient temperature}

The fermenting slurry temperatures inside each digester were measured using a MultiCon CMC-141 data logger (SIMEX Sp, 2015). The data logger was fitted with three $\mathrm{K}$-type $\mathrm{NiCr}-\mathrm{Ni}$ temperature sensors of sensitivity of approximately $41 \mu \mathrm{V}{ }^{\circ} \mathrm{C}$ and response time of $0.8 \mathrm{~s}$ in liquids (Leybold, 2014). The temperature sensors were connected to the logger using wires of about $10 \mathrm{~m}$ in length. The sensors to measure slurry temperature were located at the centre of each digester so that all points in the digester were represented by a single temperature at its centre (Baral et al., 2013). The measurements of temperature commenced on the 01 May 2015. The data were logged every second, while hourly and daily averages were automatically measured by the logging device. The logged data were retrieved and imported to the Matlab (MathWorks, 2016), which was used to visualise the variation of temperature inside the three digesters during the period under review. The choice of measuring slurry temperature at one point within the digester was based on the assumption that there is no gradient in slurry temperature inside the digester at any depth. This is supported by the results of Terradas-III et al. (2014), which showed that the average slurry temperature related to depths was $24.80{ }^{\circ} \mathrm{C}$ at $1 \mathrm{~m}, 24.50{ }^{\circ} \mathrm{C}$ at $1.4 \mathrm{~m}$, and $24.40{ }^{\circ} \mathrm{C}$ at $1.8 \mathrm{~m}$ and the mean standard deviation of the temperature at the three depths was $0.5^{\circ} \mathrm{C}$.

\section{Results and discussions}

The results are presented and discussed on the basis of the first digester because there were no significant differences observed between the values of temperature. For better graphical analysis, four graphs were plotted and are presented in the order of average daily temperature, average monthly temperature, monthly minima, maxima and average hourly temperature. The graph in Figure 2 represents the bioslurry temperature across the period. It is evident from the graph that weather conditions played a significant role in the heat transferred to the digester. This feature is seen by observing unstable temperatures and might be due to the lower absorption of heat by the bio-slurry. The figure also shows that the daily average bio-slurry temperature profiles inside the digester vary from as low as $10.20^{\circ} \mathrm{C}$ during the peak of winter to only about $28.80{ }^{\circ} \mathrm{C}$ during the peak of summer. The month of May was characterised by a daily average temperature as low as 16.70 ${ }^{\circ} \mathrm{C}$ with a maximum of $22.90{ }^{\circ} \mathrm{C}$. June saw a daily average temperature down to $10.20^{\circ} \mathrm{C}$ rising to a maximum of $19.30{ }^{\circ} \mathrm{C}$. July and August were also very cold, recording slurry temperatures ranging between $13.20^{\circ} \mathrm{C}$ and $20.80^{\circ} \mathrm{C}$ and $12.50^{\circ} \mathrm{C}$ to 23.20 ${ }^{\circ} \mathrm{C}$ respectively. The warmer months of September, October, November and December recorded, as expected, relatively higher daily average temperatures inside the digester bio-slurry, ranging from $12.80^{\circ} \mathrm{C}$ to just above $24.80^{\circ} \mathrm{C}$, between $15.80^{\circ} \mathrm{C}$ and 27.00 ${ }^{\circ} \mathrm{C}$, from 16.70 to 28.8 and from $19.10^{\circ} \mathrm{C}$ to 28.40 ${ }^{\circ} \mathrm{C}$.

Figure 3 represents the monthly average bioslurry temperature profile. It shows that during the May, which marks the beginning of winter season, the average temperature was $19.60^{\circ} \mathrm{C}$. June had a monthly average of $15.90{ }^{\circ} \mathrm{C}$, and July and August recorded monthly averages of $17.10{ }^{\circ} \mathrm{C}$ and 18.50 ${ }^{\circ} \mathrm{C}$ respectively. The warmer months of September, October, November and December recorded relatively higher monthly averages of $19.10{ }^{\circ} \mathrm{C}, 22.40$ ${ }^{\circ} \mathrm{C}, 23.00{ }^{\circ} \mathrm{C}$ and $25.40{ }^{\circ} \mathrm{C}$ respectively.

Figure 4 shows the bio-slurry temperature on the coldest and hottest days measured. Day 10 of the month of June was recorded the coldest with a monthly average temperature of 15.90 . To get a clearer picture it is necessary to focus on an hourly average temperature from $00 \mathrm{H} 00$ to $23 \mathrm{H} 59$ of the following day. Looking at the fit for the coldest day of the month of June the temperature starts to rise at around $07 \mathrm{H} 00$ and attain a maximum of 18.81 for three hours between $14 \mathrm{H} 00$ and $16 \mathrm{H} 00$. The minimum was $4.70{ }^{\circ} \mathrm{C}$, around $07 \mathrm{H} 00$. The graph shows a substantial difference between the coldest and hottest temperature, from a minimum of 5.05 ${ }^{\circ} \mathrm{C}$ at $05 \mathrm{H00}$ on 10 June to a maximum of $38.76{ }^{\circ} \mathrm{C}$ at $13 \mathrm{H} 00$ on 2 November. The graph also shows that the temperature was above $30.00{ }^{\circ} \mathrm{C}$ from $08 \mathrm{H} 00$ until $17 \mathrm{H} 00$ on 2 November. 


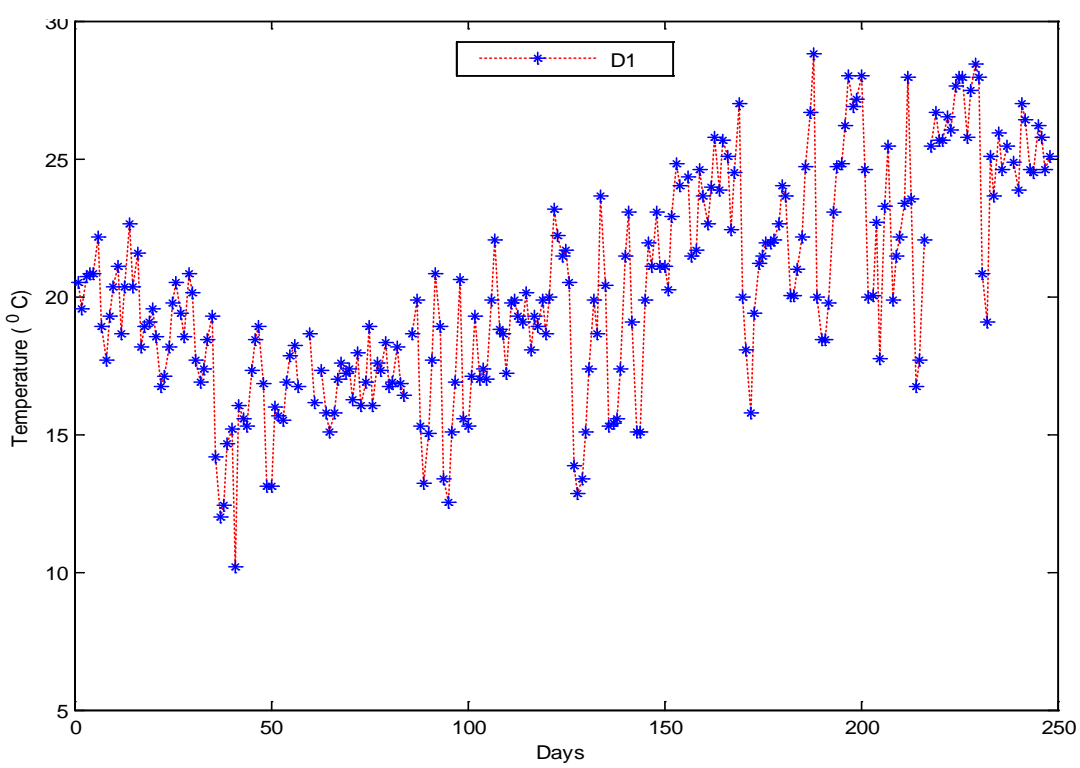

Figure 2: Bio-slurry temperature profile for combined daily average for eight months.

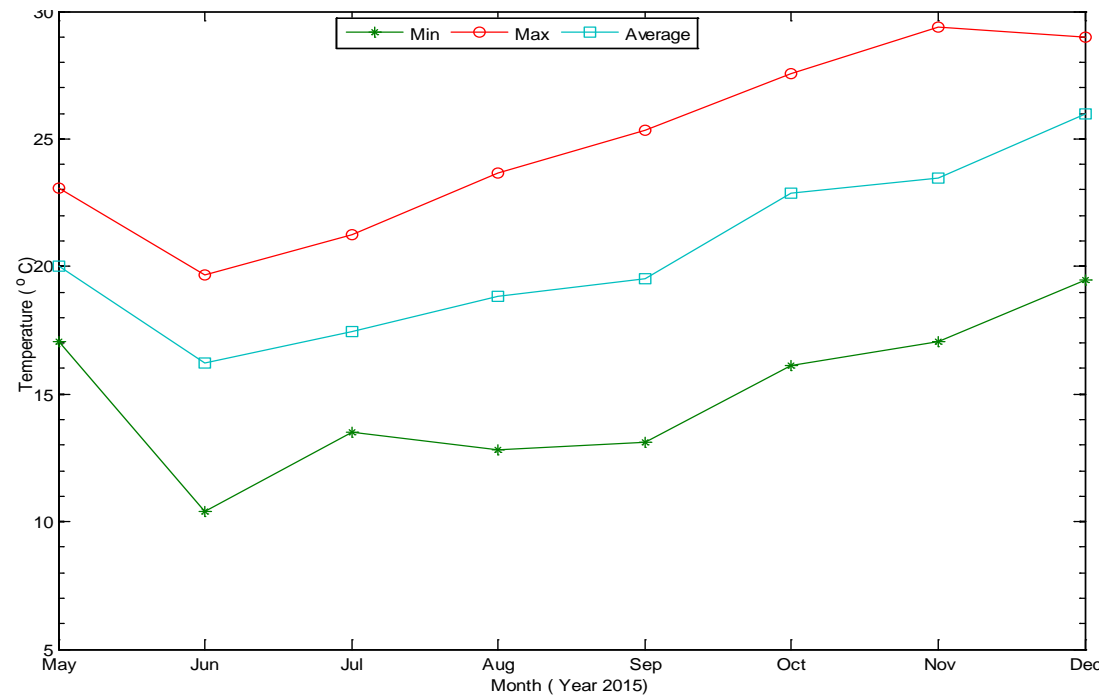

Figure 3: A monthly average bio-slurry temperature profile.

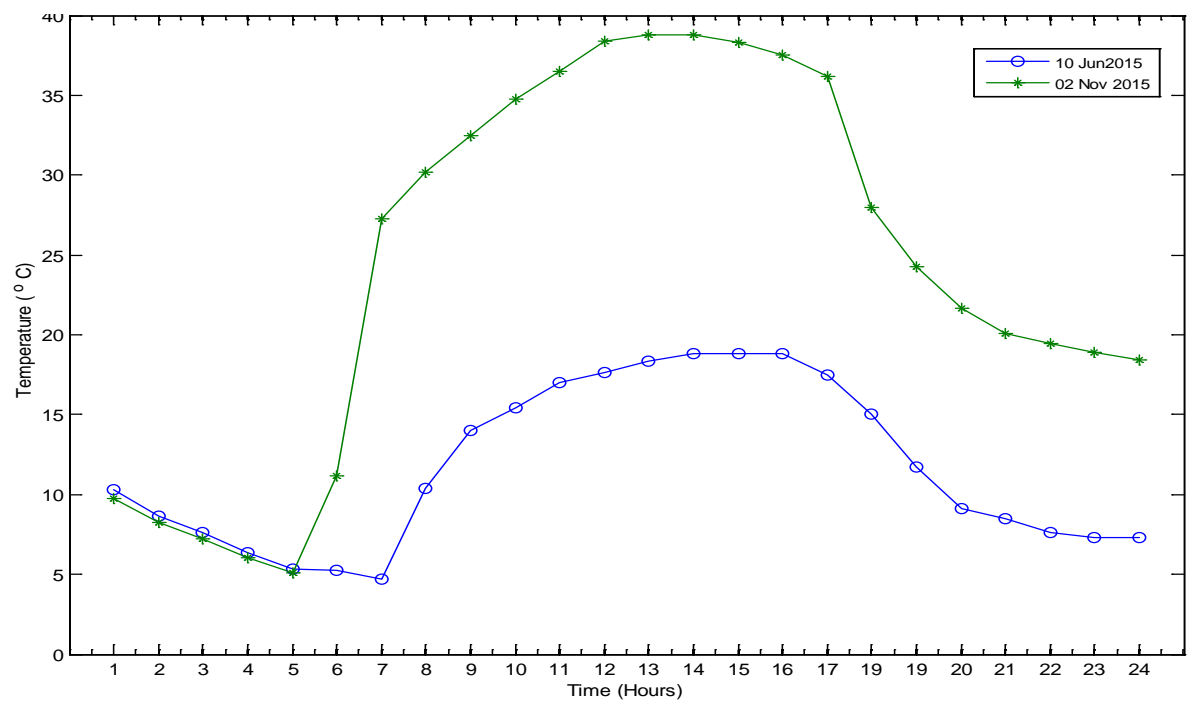

Figure 4: Internal slurry temperature profile for hourly average for the winter and summer peaks. 


\section{Conclusions}

The study monitored the operational temperature of fermenting slurry inside an underground, unheated and unstirred Deenbandhu 2000 model biogas digester by orientating a temperature sensor at the centre of a digester. The emphasis was on showing how important it is to conduct a long-term study of slurry temperature profile at local level. On the basis of the obtained results, the following conclusions may be drawn:

1. The average daily operational temperature of the digester at Vele Secondary School ranged between psychrophilic $\left(10.32^{\circ} \mathrm{C}\right)$ and mesophilic $\left(29.80^{\circ} \mathrm{C}\right)$ between May and December 2015.

2. The slurry temperature in both winter and summer months started to rise from low to high mainly at $08 \mathrm{H} 00$ and dropped from high to low mainly at $17 \mathrm{H} 00$.

3. The biogas digesters were sometimes operating at an optimum mesophilic temperature range in summer hours. For example, in the hottest month (November) the system's temperature was over $35.00{ }^{\circ} \mathrm{C}$ for seven hours, between $11 \mathrm{H} 00$ and $17 \mathrm{H} 00$.

4. Bio-slurry microorganisms inside the digesters suffer severely during the evening and early morning hours of the day when the minimum temperature is below $20.00^{\circ} \mathrm{C}$.

In view of all this, it is recommended that in cold weather conditions, especially during winter months and early morning hours, additional heat should be provided to increase the slurry temperature within the digester system. This study provides information to support decisions as to installing solar assisted biogas digesters in the area. Further study is needed to estimate the amount of heat required to raise the temperature of these biogas digesters in order to reach an optimum temperature of mesophilic operation. This can be done using the sets of primary data of this study. In addition, future studies should endeavour to relate bio-slurry temperature to air temperature, soil temperature, soil moisture as well as the amount of rainfall. Financial support would be needed to acquire measuring materials.

\section{Acknowledgements}

The research is part of a project under the "Global Change Grand Challenge National Research Plan" under the auspices of the South African Department of Science and Technology's "Global Change, Society and Sustainability Research Programme". The study was funded by the DST and managed by the National Research Foundation in collaboration with the University of Cape Town. The authors would like to thank reviewers for their constructive comments, and Dr Isaac Ndlovu for proofreading the manuscript.

\section{References}

Aburas,R., Hammad, M., Abu-Reesh, I., Hiary, S.E. and Qousous, S. 1995. Construction and operation of a demonstration biogas plant, problems and prospects. Bioresource Technology 53 (2): 101-104.

Alkhamis, T.M., El-khazali, R. and Kablan, M. M. 2000. Heating of a biogas reactor using a solar energy system with temperature control unit. Solar Energy 3 (69): 239-247.

Amigun, B. and Blottnitz, H. 2007. Investigation of scale economies for African biogas installations. Energy Conversion and Management 48 (12): 3090-3094.

Amigun, B. and Blottnitz, H. 2010. Capacity-cost and location-cost analyses for biogas plants in Africa. Resources Conservation and Recycling 55 (1): 6373.

Appels, L., Baeyens, J., Degrève, J. and Dewil, R. 2008. Principles and potential of the anaerobic digestion of waste-activated sludge. Progress in Energy and Combustion Science 34 (6): 755-781.

Baral, S., Pudasaini, S. P., Khanal, S. N. and Gurung, D. B. Mathematical modelling, finite element simulation and experimental validation of biogas-digester slurry temperature. 2013. International Journal of Energy and Power Engineering 3 (2):128-135.

Bhat, P. R., Chanakya, H. N. and Ravindranath, N. H. 2001. Biogas plant dissemination: success story of Sirsi, India. Energy for Sustainable Development 5 (1): 39-46.

Cheng, S., Huba, E. M., Li, A. Z. and Mang, H. P. 2013. A review of prefabricated biogas digesters in China. Renewable and Sustainable Energy Reviews 28 (14): 738-748.

Chen, Y. R. and Hashimoto, A. G. 1979. Kinetics of methane fermentation. Biotechnology and Bioengineering Symposium 8: 269-282.

Dhaked, R. K., Singh, P. and Singh, L. 2010. Biomethanation under psychrophilic conditions. Waste Manage 30 (12): 2490-2496.

Hlungwani, V. 2009. Use of biogas energy a first for Limpopo. Available at: http://www.sowetanlive.co.za/.

Huang, J.and Crookes, R. J. 1998. Assessment of simulated biogas as a fuel for the spark ignition engine. Fuel 77 (15): 1793-1801.

Igoni, A.H., Ayotamuno, M.J., Eze, C.L., Ogaji, S.O.T. and Probert, S.D. 2008. Designs of anaerobic digesters for producing biogas from municipal solidwaste. Applied Energy 85 (6): 430-438.

Kalia, A. K. and Kanwar, S. S. 1998. Long-term evaluation of a fixed dome janata. Bioresource Technology 65 (1-2): 61-63.

Karellas, S., Boukis, I. and Kontopoulos G. 2010. Development of an investment decision tool for biogas production from agricultural waste. Renewable and Sustainable Energy Reviews 14 (4): 1273-1282.

Kotzé, P. 2014. New projects lends from nature to power up village: The Water Wheel, November/December. 
Lansing, S. 2008. Waste treatment and biogas quality in small-scale agricultural digesters. Bioresource Technology 99 (3): 5881-5890.

Leybold didactic, 2014. Temperature probe, NiCr-Ni. Available at: http://www.ld-didactic.de/.

Limmeechokchai, B. and Chawana, S. 2007. Sustainable energy development strategies in the rural Thailand: The case of the improved cooking stove and the small biogas digester. Renewable and Sustainable Energy Reviews 11 (5): 818-837.

Martin, A. R. and Khan, E. U. Review of biogas digester technology in rural Bangladesh. Renewable and Sustainable Energy Reviews 62 (10): 247-259.

MathWorks, 2016. About us: The MathWorks. Available at: http://www.mathworks.com= www.mathworks.com

Maxwell, V. 2014. Biogas in rural South Africa - VBN. Available at: vbn.aau.dk/ws

Mukumba, P., Makaka, G. and Shonhiwa, C. 2015. An assessment of the performance of a biogas digester when insulated with sawdust. International Journal of Energy and Power Engineering 4 (2): 24-31.

Mutale Municipality, 2012. FINAL IDP 2012 final Mutale Municipality. Available at: www.mutale.gov. za.

Mwakaje, A. G. 2008. Dairy farming and biogas use in Rungwe district, South-west Tanzania: A study of opportunities and constraints. Renewable and Sustainable Energy Reviews 12 (8): 2240-2252.

Mwirigi, J. W., Makenzi, P. M. and Ochola, W. O. 2009. Socio-economic constraints to adoption and sustainability of biogas technology by farmers in Nakuru Districts, Kenya. Energy for Sustainable Development 13 (2): 106-115.

NERSA. 2013. Registers biogas production activities in rural areas in terms of the gas act, 2001 (Act no. 48 of 2001). Pretoria: National Energy Regulator of South Africa.

Parawira, W. 2009. Biogas technology in sub-Saharan Africa: status, prospects. Reviews in Environmental Science and Biotechnology 8 (2): 187-200.

Pham, C. H., Triolo, J. M. and Sommer, S. 2014. Predicting methane production in simple and unheated biogas digesters at low temperatures. Applied Energy 136 (24): 1-6.

SANEDI, 2014. SANEDI Waste-To-Energy Projects GreenCape. Available at: http://greencape. co.za/assets/Sector-files/waste/SANEDI-WTEProjects.pdf.

Shaheen, M. and Nene, A. A. 2014. Thermal simulation of biogas plants using matlab. International. Journal of Engineering Research and Applications 4(10): 2428.

Singh, L., Maurya, M. S., Ramana, K. V. and Alam, S. I. 1995. Production of biogas from night soil at psychrophilic temperature. Bioresource Technology 53 (2):147-149.

SIMEX Sp: Data recorders. Available at: http://www. simex.pl.

Terradas-III, G.,Triolo, J M., Pham, C H., Martí-Herrero, $\mathrm{J}$ and Sommer, S G. 2014. Thermic model to predict biogas production in unheated fixed dome digesters buried in the ground. Environmental Science and Technology 48 (6): 3253-3262.

Walekhwa, P. N., Mugishaa, J. and Drakeb, L. 2009. Biogas energy from family-sized digesters in Uganda: Critical factors and policy implications. Energy Policy 37 (7): 2754-2762.

Weatherford, V. C., and Zhai, Z. J. 2015. Affordable solar-assisted biogas digesters for cold climates: Experiment,model, verification and analysis. Applied Energy 146 (10): 209-216.

Xiaohua, W., Chonglan, D., Xiaoyan, H., Weiming, W., Xiaoping, J. and Shangyun, J. 2007. The influence of using biogas digesters on family energy consumption and its economic benefit in rural areas comparative study between Lianshui and Guichi in China. Renewable and Sustainable Energy Reviews 11 (5): 1018-1024. 